М. Карне. - Мосва : Прогресс, 1991. - 384 с. 8. Психология одаренности детей и подростков / под ред. Н. С. Лейтеса. - Москва : Академия, 1996. - 416 с. 8. Серапулова Є. Виховання обдарованої дитини / С. Серапулова // Початкова школа. - 2000. - № 2. - С. 3-5. 9. Чернишова Д. Організація роботи з обдарованими учнями // Обдарована дитина. - 2001. № 7. - С. 4-7. 10. Янковчук М. М. Психологічна організація індивідуальної освіти та виховання обдарованих дітей / М.М.Янковчук // Практична психологія та соціальна робота. - 2008. - № 3 (108). - С. 63-66. 11. Янковчук М. М. Задатки як функціональна передумова розвитку обдарованої особистості / М. М. Янковчук // Актуальні проблеми психології: Психологія навчання. Генетична психологія. Медична психологія / [за ред. С. Д. Максименка]. - Київ : ДП «Інформаційно-аналітичне агентство», 2007. - Т. Х. Вип. 2. - С. 651-661. 12. Янковчук М. М. Огляд досліджень впливу сім’ї на розвиток обдарованих дітей / М. М. Янковчук // Актуальні проблеми психології: Психологія навчання. Генетична психологія. Медична психологія/ [за ред. С. Д. Максименка]. - Київ : ДП «Інформаційно-аналітичне агентство», 2008. - Т. Х. - Вип. 9. - С. 519-530.

УДК 371.134:373.3

Людмила Федорова

\title{
ПЕДАГОГІЧНИЙ ТАКТ - ОСНОВА ПРОФЕСІЙНОЇ ПІДГОТОВКИ ВЧИТЕЛЯ ПОЧАТКОВОЇ ШКОЛИ
}

Федорова Л. Г. Педагогічний такт - основа професійної підготовки вчителя початкової школи.

У статті проаналізовано основні дефініції поняття «педагогічний такт» та обгрунтовано значущість цього феномену у професійній підготовці вчителя початкової школи, визначено та розкрито зміст основних компонентів цього поняття. Акцентовано увагу на ідеях В. Сухомлинського про педагогічний такт учителя початкових класів.

Ключові слова: такт, педагогічний такт, особистість, учитель початкових класів, професійна підготовка.

Федорова Л. Г. Педагогический такт - основа профессиональной подготовки учителя начальной школы.

В статье проанализированы основные дефиниции понятия «педагогический такт» и обоснована значимость этого феномена в профессиональной подготовке учителя начальной школы, определено и раскрыто содержание основных компонентов данного понятия. Акцентировано внимание на идеях В.Сухомлинского о педагогическом такте учителя начальных классов.

Ключевые слова: такт, педагогический такт, личность, учитель начальных классов, профессиональная подготовка.

Fedorova L. G. Pedagogical tact is a basis of the professional training of a primary school teacher.

In the article the basic definitions of the concept «pedagogical tact» were analyzed and its significance in the professional training of a primary school teacher was grounded, a content of the basic components of the given concept was determined and shown. An attention to V. Sukhomlinsky ideas about pedagogical tact of a primary school teacher was paid.

Key words: tact, the pedagogical tact, personality, primary school teacher, 
professional training.

Аналіз психологічної, педагогічної та спеціальної літератури показав, що такт - це почуття міри, що формує вміння людини поводити себе пристойно, належним чином [5, c. 585], а педагогічний такт - це спеціальне професійне вміння вчителя, засноване на почутті міри, що грунтується на повазі до особистості, уважному ставленні й довірі до неї i проявляється в умінні вчителя поводиться належним чином стосовно інших учасників педагогічного процесу, у техніці й мистецтві взаємодії і спілкування.

У контексті останніх досліджень щодо професійної підготовки вчителя особливого значення набувають питання педагогічного такту взагалі і вчителя початкової школи зокрема.

Одним із засобів діяльності вихователя, спрямованим на формування особистості учня, $\epsilon$ педагогічний такт, а джерелом його прояву, на думку В. Сухомлинського, є любов до дитини [7, с. 358]. Отже, педагог робить висновок по те, що тільки гуманний учитель може бути тактовним.

Слід відзначити, що всі питання теорії та практики педагогічної діяльності В. Сухомлинський розв'язував, керуючись принципом гуманізму, провідною рисою якого вважав визнання головною цінністю буття людини, благо людського життя. У працях педагога гуманність розглядається як складна інтегративна духовна якість особистості, яка охоплює всі сторони іiі розвитку. Особливо важливою така риса $є$ для представника педагогічної професії, що $\epsilon$ авторитетом для розвитку суспільства, найкращим його представником, який засвоїв ідеали існування суспільства. У концепції В. Сухомлинського «повага до гідності учня, увага до його почуттів і вміння торкнутись їх сакральності повинні бути пов’язані з ласкою і добром, ... чим більше тонкості і тактовності в цій сердечній сфері взаємовідносин, тим чутливішою стає дитина, ... тим більше прагне бути кращою» [7, с. 357].

В. Сухомлинський уважав необхідним застосування педагогічного такту у процесі формування особистості дитини - від того, як вплине вчитель на серце учня, таким воно стане - ніжною квіткою або засушеною корою. Заповітною мрією кожного педагога є «серце вихованця, чутливе до кожного слова вихователя; відгук дитячої душі, мов ніжної струни на тонку музику душі вихователя» [8, с. 635].

На підставі аналізу праць В. Сухомлинського можна виокремити особистісні характеристики тактовного вчителя: справедливість, доброта, терпіння, наполегливість, турбота, гумор, культура поведінки. Саме педагогічний такт забезпечує створення ситуації успіху та радості пізнання шляхом залучення учнів до життя у світі книжок; захист від душевної самотності кожної дитини; розвиток в учнів оптимізму [8].

Педагогічний такт у концепції В. Сухомлинського передбачає сукупність засобів, методів, прийомів педагогічної дії, яка реалізовується вчителем у конкретній педагогічній ситуації як педагогічна підтримка учнів для досягнення кращих результатів у навчанні та вихованні окремих учнів і дитячого колективу загалом в умовах особистісного підходу щодо формування всебічно розвиненої особистості [8].

Отже, педагогічний такт- це міра педагогічного впливу, що виявляється у доброзичливому ставленні вчителя до учнів, його вмінні тримати себе, у його висловлюваннях, засобах виховного впливу.

Аналіз наукових праць дослідників проблеми педагогічного такту дозволив зробити висновок про те, що найбільш досліджуваними категоріями, пов'язаними 3 проблемою 
педагогічного такту, є: етичні знання й уміння представника педагогічної професії, що є передумовою педагогічного такту (Л. Альошина, В. Гусоєв, В. Писаренко, І. Писаренко, В. Чернокозова, I. Чернокозов); педагогічна культура, компонентом якої є педагогічний такт (М. Васильєва, О. Гармаш, М. Гриньова, І. Ісаєв, П. Садчикова, Л. Спірін); стиль поведінки, у якому виявляється педагогічний такт учителя (С. Акбієв, А. Водейко, Д. Самуйлєнков, С. Саннікова); мистецтво спілкування вчителя з іншими учасниками педагогічного процесу (А. Бардін, М. Богданова, А. Борисова, Б. Бушелєва, Е. Гришин).

Водночас слід відзначити, що дослідження педагогічного такту як основи професійної підготовки вчителя початкової школи не відображено повною мірою в науковій літературі.

У зв'язку з цим метою статmі $\epsilon$ : аналіз основних дефініцій поняття «педагогічний такт» та обгрунтування значущості цього феномену у професійній підготовці вчителя початкової школи.

За нашим припущенням, основою педагогічного такту є дотримання міри педагогічної доцільності в застосуванні навчально-виховних впливів на учнів, яка регулюється та залежить від конкретних завдань навчально-виховного процесу. Цікавими для нас виявилися ідеї І. Страхова про зміст педагогічної діяльності, що виражається в оптимізації педагогічних впливів, їх відповідності кожній психолого-педагогічній ситуації, врахуванні індивідуальних особливостей і можливостей особистості учня, його навчальної підготовки, ставленні до навчання, психологічного стану й обставин в умовах, у яких відбувається педагогічний вплив [6].

Глибоким психологічним змістом вирізняється думка про те, що педагогічний такт це почуття міри в застосуванні засобів педагогічного впливу на дітей, що виявляється в умінні вчителя поводитися належно, гідно, просто й переконливо розмовляти з вихованцями.

Аналіз теоретичних джерел і педагогічної практики дає підстави стверджувати, що основою педагогічного такту є глибокі знання психології дітей, увага та повага до особистості кожного, враховування психологічних особливостей, індивідуальних рис і можливостей.

Учитель початкової школи - це вчитель, в обов'язки якого входить навчання i виховання учнів з урахуванням специфіки різних предметів та вікових особливостей молодших школярів, формування загальної культури особистості, соціалізації, усвідомленого вибору i засвоєння соціальних програм, розвиток самостійності та самоорганізованості в учнів шляхом формування компетентностей різних напрямів.

Професійні функції, що покладено на вчителя початкових класів, мають свою специфіку, що зумовлена особливостями об'єкта його діяльності (учні початкової школи), віковими і психологічними характеристиками, а також умовами педагогічної діяльності (постійне спілкування - взаємодія з учнями класу, зв'язок з батьками учнів).

Виховний аспект реалізації педагогічного такту забезпечується тим, що вчитель початкових класів покликаний докладати зусиль для формування системи моральних принципів, естетичних почуттів та ідеалів учня, формування наукового світогляду, розширення кругозору та духовний розвиток особистості. Саме від вчителя початкових класів залежить ефективність згуртування колективу, створення та збереження колективних традицій і забезпечення сприятливого клімату для формування кожної особистості в ньому.

Виконання вчителем початкової школи навчальної функції передбачає керівництво провідною діяльністю молодшого школяра - навчанням та виявляється в організації учнів задля оволодіння знаннями, вміннями і навичками з основ наук, забезпеченні умов для інтелектуального розвитку учнів, озброєння їх методами самостійної пізнавальної діяльності. 
Специфіку реалізації навчальної функції вчителем початкової школи підкреслював В. Сухомлинський, зазначаючи, що одним із провідних є завдання збудувати настільки міцний фундамент знань, щоб учителям, які працювали б після початкової школи, взагалі не було потрібно замислюватись над фундаментом [9].

Важливою $є$ інформаційна функція вчителя початкових класів, що передбачає поширення педагогічних знань серед батьків, працівників соціальної і виробничої галузей. Учитель початкових класів повинен бути авторитетом і для батьків учнів, носієм науково обгрунтованих психолого-педагогічних знань, які він використовує для визначення типу родини, стилю сімейного виховання та визначення на цій основі методики та форм роботи 3 батьками і дітьми.

Для професійної підготовки вчителів початкової школи особливого значення набуває змістова характеристика поняття, яке вивчається (педагогічний такт), тобто його структура.

Складниками педагогічного такту вчителя $є$ : вольові якості, інтелектуальні особливості, комунікативні вміння й особистісні характеристики, найважливішими з яких є: повага до учнів, доброзичливість, довіра у поєднанні з вимогливістю, урахування вікових особливостей та можливостей кожного з них. Зупинимось на характеристиці кожного з них.

Особистісно-вольовий компонент педагогічного такту вчителя початкових класів передбачає індивідуально-психологічні якості, які дозволяють грамотно будувати міжособистісні стосунки, ефективно взаємодіяти з людьми у спільній діяльності. Ці якості виявляються у рівнях комунікативного (засоби транслювання інформації), інтерактивного (способи й прийоми психологічного впливу, активної взаємодії у спільній діяльності) та перцептивного (міжособистісне сприйняття, оцінка та взаєморозуміння) аспектів спілкування.

Інтелектуальний компонент стимулює пізнавальну й самостійну діяльність студента, передбачає наявність знань про такт, педагогічний такт, усвідомлення значущості цього поняття для власної особистості. Від представника педагогічної професії вимагається постійне вдосконалення власного інтелектуального рівня. Не можна уявити собі вчителя, який, здобувши освіту, не відчував би потреби постійно підвищувати свій рівень знань, займатися самовдосконаленням. У процесі засвоєння певних знань у людини розширяється світогляд, змінюється ставлення до світу речей і людей, з'являється усвідомлення необхідності нових знань. Тактовна людина - це, як правило, інтелігентна людина, у якої розвинений інтелект і розуміння необхідності розумно ставитися до інших. Наявність у педагогічному такті інтелектуального компонента зумовлює необхідність приділення уваги формуванню знань про такт і тактовність, значущість цих особистісних характеристик для представника педагогічної професії - про способи виявлення такту у взаємодії з іншими; забезпеченню сформованості педагогічного такту.

Комунікативний компонент педагогічного такту характеризується наявністю комунікативних, організаторських, конструктивних, перцептивних, інтерактивних умінь, які дозволяють організувати навчальний процес у різноманітних формах. Наявність цього компонента сприяє формуванню вмінь будувати діалог у навчальній ситуації, організовувати та координувати висловлювання учасників діалогу, привертати увагу співрозмовника, структурувати навчальну інформацію у формі діалогу, слухати співрозмовника. Учителям початкових класів притаманні правильність мовлення в комунікації з учнями (наслідування вчителя учнями), точність мовлення (передбачає пояснення зрозумілою для них мовою), емоційність мовлення (ставлення до співрозмовників), а також характеристика, що забезпечує сприйняття і засвоєння нової для учнів навчальної інформації. 
Рефлексивний компонент педагогічного такту вчителя початкових класів передбачає наявність здатності до самоспостереження, самопізнання, самоаналізу, самоконтролю та узагальнення отриманих знань, умінь, навичок, співвіднесення себе, своїх можливостей 3 тим, чого вимагає обрана професія.

Отже, зазначене вище дає підстави стверджувати, що педагогічний такт учителів початкових класів - це складне особистісне утворення, що характеризується почуттям міри в застосуванні педагогічного впливу на молодших школярів, у взаємодії і спілкуванні з учнями та їх батьками, урахованні особливостей віку дітей і специфіки професійних функцій. Структура цього феномену містить особистісно-вольовий, інтелектуальний, рефлексивний і комунікативний компоненти. На формування цих компонентів слід звернути увагу під час професійної підготовки майбутнього вчителя початкових класів у вищому педагогічному навчальному закладі.

\section{Література}

1. Васильсва М. П. Сучасний стан дослідження питань професійної деонтології / М. П. Васильєва, М. К. Подберезський // Засоби навчальної та науково-дослідної роботи: [зб. наук. праць] / за заг. ред. В. І. Свдокимова і проф. О. М. Микитюка. - Харків, 2010. Вип. 33. - С. 177. 2. Гончаренко С. У. Український педагогічний словник / Семен Устинович Гончаренко. - Київ : Либідь, 1997. - 376 с. З. Кутняк І. Особливості підготовки майбутніх учителів початкових класів у світлі завдань сучасної вищої школи / І. Кутняк // Початкова школа. - 2014. - № 10. - С. 28-30. 4. Мірошник 3. М. Структура особистості вчителя початкових класів: рольовий підхід : [монографія] / Зоя Михайлівна Мірошник. Харків : ФЛП Шейнина Е. В.; ХНПУ, 2011. - 306 с. 5. Словник іншомовних слів / авт. колектив: Л. І. Шевченко, О. І. Ніка, О. І. Хом'як, А. А. Дем'янюк; за ред. Л. І. Шевченко. Київ : АРІЙ, 2008. - 672 с. б. Страхов И. В. Психологические основы педагогического такта: [пособ. для ин-тов] / Иван Владимирович Страхов. - Саратов, 1972.- 180 с. 7. Сухомлинський В. О. Методика виховання колективу / В. О. Сухомлинський // Вибрані твори: в 5 т. - Київ, 1976. - Т. 1. - С. 613-637. 8. Сухомлинський В. О. Не бійтеся бути ласкавим / В. О. Сухомлинський // Вибрані твори: в 5 т. - Київ, 1977. - Т. 5. - С. 317-359. 9. Сухомлинский В. А. Сто советов учителю / В. А. Сухомлинский. - Київ : Рад. школа, 1984.- 254 с. 10. Федорова Л. Г. Формування педагогічного такту - основа професійної підготовки майбутнього фахівця / Л. Г. Федорова // Актуальные вопросы в современной науке: [сб. научных докладов]. - Варшава, 2013. - Часть 3/2. - С. 42-50.

УДК 37.013 .42

Юлія Чернецька

\section{ПОНЯТІЙНА ТРІАДА «СОЦІАЛІЗАЦІЯ - ДЕСОЦІАЛІЗАЦІЯ - РЕСОЦІАЛІЗАЦІЯ» В КОНТЕКСТІ ВИВЧЕННЯ СОЦІАЛЬНО-ПЕДАГОГІЧНИХ ПРОБЛЕМ НАРКОЗАЛЕЖНИХ ОСІБ}

Чернецька Ю. І.Понятійна тріада «соціалізація - десоціалізація - ресоціалізація» в контексті вивчення соціально-педагогічних проблем наркозалежних осіб.

У статті розкрито зв'язок дефініцій «соціалізація», «десоціалізація» і «ресоціалізація», який представлено як понятійну тріаду. Розроблено наукові основи і подано сутнісні характеристики процесу ресоціалізації наркозалежних осіб з позицій соціальної педагогіки. Розкрито сутність провідних понять «ресоціалізація», «ресоціалізація наркозалежних».

Ключові слова: понятійна тріада, соціалізація, десоціалізація, ресоціалізація, 